\title{
Connecting Public Health Disaster with the Environment in the Context of COVID 19 Pandemic Experience from an African Perspective (2)
}

\author{
John Mark Ogu and Graduate Student of Duquesne University Pittsburgh
}

Duquesne University Pittsburgh

* Correspondence: johnmark.ogu@gmail.com

\begin{abstract}
Public health disaster is linked positively to security and socio-economic development because epidemics and pandemics are not only threats to human health; they also hurt economic and sociopolitical life. The outbreak of COVID-19 is an excellent example. It caused anxiety, fear, and worry about biosecurity and micro-organisms that can be used as bioweapons. It also disrupts the economic and socio-political life of people. Therefore, there is a connection between health, environment, and security. These three elements connect all human beings directly or indirectly. In the recent past, Africa and West Africa have witnessed some epidemics like Ebola and lesser fever that threatened the region and the global community. Health, environment, disease, and the divinity in African are linked together because ill-health is understood from religious and environmental backgrounds.
\end{abstract}

Keywords: Africa; COVID-19, Pandemic; Disaster; Public Health

\section{Introduction}

Recently, many places have been threatened by public health disasters, such as earthquakes, hurricanes, tornados, epidemics, and the current COVI-19 pandemic. These disasters caused panic, sickness, death, infection, and migration, and disrupt socio-economic activities. The effects of these public health disasters are much on the global community as they affect many facets of life, school, economics, health, and security. Amid the effects and problems each of these disasters brought, there is an underlining reality that the world is a community (interconnected and interrelated) because each disaster has some effects on the global community, directly or indirectly. It implies that human beings and other creatures have some relationship and connection. Therefore, this paper looks at the connection between public health disaster with the environment in the context of the COVID-19 pandemic from an African perspective. It focuses on infectious diseases and the global health community.

\section{The Global Health Community}

A pandemic like COVID-19 briefly revives the understanding and sense that human beings are a global community, dwelling and working on the same planet, where an individual health problem may cause severe health concern to the entire community. It makes us understand that no one is saved alone and that humanity can only be saved together or as a community. ${ }^{1}$ This is captured in African philosophy that says a person cannot exist 
independently, but corporately. Hence in Africa, a person owns his/her existence to others, and universal (corporal and spiritual bodies.) ${ }^{2}$ Therefore, if human beings are interrelated and everything is connected, in that case, it is difficult to assume that COVID-19 is not related to our way of approaching reality and claim of being a master of ourselves and the universe. It is not to say that the harm human beings are doing to nature is the cause of the pandemic; instead, the world is getting disintegrated and forgotten that we must live in solidarity and cooperation to achieve better things. ${ }^{3}$

This pandemic (COVID-19) has exposed human vulnerability and makes the global community understand how fragile we are amid our technological, scientific, and medical developments. ${ }^{4}$ However, COVID-19 is not the first global pandemic experience. Since the 16th century, the world had experienced more than three pandemics per century, which occurred at different times with varied morbidity and mortality rates. For example, the Spanish (1918-1919) infected about $20 \%$ of the world population, killing between 40-50million people. Other major documented pandemics are Asian flu (1957-1958), Hong Kong flu (19681969), Swine flu (2009-2000. $)^{5}$ in addition to Ebola, which first appeared in 1976 and has reoccurred 14times with its peak in 2014-2015 and the COVID-19 2002. ${ }^{6}$

However, the experience of the COVID-19 pandemic and its effects calls on us to "rethink our styles of life, our relationship, the organization of our societies and above all, the meaning of human existence. ${ }^{7}$ It is no doubt that COVID-19 Pandemic explains the dynamism in social and health relationship in the global community because an outbreak of epidemic or pandemic in one part of the world is a threat to the global community like SARS, Ebola, and the ongoing COVID 19. These are threats to the world's security, economy, and health. Ebola and COVID-19 have seriously affected the global economy because of the various restrictions during their outbreaks. The periods witnessed restrictions at local and international levels as schools, businesses, and borders were closed. The airlines and cruise ship companies suffered most as many countries stopped aircraft and cruise ships into their countries. ${ }^{8}$ It supports the idea that everything in the universe is connected. All things in the world are interconnected and interrelated, as human beings are connected as brothers and sisters. We are also pilgrims journeying together in a world of uncertainties and infinitude. Each creature is connected with human beings and the heavenly and earthly bodies - sun, moon, river, and earth.

${ }^{2}$ Isiguzo Andrew I et al., The Igbo concept of a Person, Istituto Italiano per l'Africa e l'Oriente, vol. 59, no 2, 2004, 239.

${ }^{3}$ Francis, Encyclical Letter Fratelli Tutti (on Fraternity and Social friendship), Vatican City, Libreria Editrice Vatican, 2020, 34.

${ }^{4}$ Francis, Encyclical Letter Fratelli Tutti (on Fraternity and Social friendship), Vatican City, Libreria Editrice Vaticana, 2020, no 32-33.

${ }^{5}$ Donaldson Liam and Rutter Paul D, Donaldsons' Essential Public Health $4^{\text {th }}$ Edition, New York, CRC Press, 2018, 108-109.

${ }^{6}$ Afolabi Michael Olusegun, Public Health Disaster: A Global Ethical Framework, Switzerland, Springer, 2018,26-27.

${ }^{7}$ Francis, Encyclical Letter Fratelli Tutti (on Fraternity and Social friendship), Vatican City, Libreria Editrice Vaticana, 2020, no 32-34.

${ }^{8}$ Shah Sonia, Pandemic Tracking Contagions from Cholera to Ebola and Beyond, New York, Picador, 2016, 203. 
There is a connection between human health and the environment because nature is both the cause and source of infectious and vector diseases as well as medicine and antibiotics. ${ }^{9}$ For example, Ebola is an infectious disease that belongs to the Filoviridae family. It is believed that wild animals can transmit it to humans. ${ }^{10}$ Humans also transmit diseases from one place to another because people's movement from the infectious region provides the opportunity for infections to move to noninfectious regions. For example, malaria plasmodium lives for about three years in the bloodstream. Human movement from a malaria region to a nonmalaria region provides the opportunity for the vector's movement. Human vector diseases flourish on society's border and spread as people seek to avoid material hardship by trading social risk for biomedical ones. Therefore, mobility, social status, and compromised health serve as the three ways for understanding the human role in malaria and other infectious disease transmissions. ${ }^{11}$ Again, the health and security effects of pollution and environmental degradation are many. The pollution of one end of the world is also a threat and pollution of other parts of the earth because plants, seas, rivers, land, and other creatures are interrelated and interconnected. Moreover, the environment is a primary determinant of health because a healthy environment promotes good health and development. In contrast, a polluted and degraded environment causes illness and chaos. It is worth noting that the impacts of human actions on the environment are increasing the menace of infectious diseases in humans; over $60 \%$ of infectious diseases originate from animals, especially wild animals. If the human impact on the environment is reduced, it will reduce future epidemics and pandemics outbreaks. ${ }^{12}$

Although the emergence of COVID -19 grips the global community with fear, uncertainty, anxiety, and loss of confidence in global health governance. The dread of these viruses brought pervasive panic because of its contagion. However, amid these crises and the ugly situation brought by COVID-19, there exist the image of national and international solidarity and cooperation. The tremendous efforts and commitment of healthcare workers to tackle the virus despite all odds and risk is highly applaudable. Local communities organized welfare packages for the less privileged and vulnerable persons in their areas to alleviate their economic and social burden due to this pandemic. These were ways of encouraging the poor and vulnerable that "we are all in this together." Governments of various nations stepped in with social, economic, and health services packages and assistance to support their citizens. It also brought international solidarity as nations share and exchange knowledge,

${ }^{9}$ World Health Organization's Regional Office Europe, Protecting nature protects health - lessons for the future from COVID-19, https://www.euro.who.int/en/health-topics/healthemergencies/coronavirus-covid-19/news/news/2020/6/protecting-nature-protects-health-lessons-forthe-future-from-covid-19 accessed November 25, 2020

${ }^{10}$ Afolabi Michael Olusegun, Public Health Disaster: A Global Ethical Framework, Switzerland, Springer, 2018, 26.

${ }^{11}$ County Brandon, Migration, Mortality and Measurement: A Reassessment of the Historiographical Use of Relocation Cost with Attention to the Office du Niger, Soudan Francais (Mail) 1925-1945, in Falola Toyin and Heaton Matthew. M. ed, Health knowledge and Belief system in Africa, North Carolina, Carolina Academic press, 2008, 230.

${ }^{12}$ World Health Organization's Regional Office Europe, Protecting nature protects health - lessons for the future from COVID-19, https://www.euro.who.int/en/health-topics/healthemergencies/coronavirus-covid-19/news/news/2020/6/protecting-nature-protects-health-lessons-forthe-future-from-covid-19 accessed November 25, 2020. 
information, resources, and expertise to control this pandemic. In response the virus and its menace, the WHO sets up the COVID-19 Solidarity Response Fund, which has generated over $\$ 70$ million US Dollars. Some regional organizations have taken strong proactive measures, sharing information and receiving testing kits, medical supplies, and medical staff donations. However, some countries are complacent about the virus. The global community should maintain this spirit of solidarity and cooperation that the pandemic brought to promote future solidarity and support for the most vulnerable nations and individuals. ${ }^{13}$ Additionally, it has brought in short term cleaner air, reduced carbon emissions, and less noise because of restriction and reduction in transport and economic activities. ${ }^{14}$

\section{Infectious Diseases a Security Threat}

Infectious diseases have long been considered a security threat to public health and state security because the emergence of an infectious disease poses a security threat to individuals and the nation at large; because it comes with fear, anxiety, fear of bioterrorism, and weaponization. In 1851at First International Sanitary Conference, infectious disease was perceived as a threat to the population because of its effects on the economy, movement, and other human endeavor aspects. ${ }^{15}$ Understanding infectious disease as a security threat is linked with medical culture because the reigning languages (words) of medicine about infectious diseases are synonymous with security words and statements, such as fight, attack, and combat. We fight illness; we fight a war, arm ourselves with vaccines and medicines, and combat infections. These words are also used in a military expedition. Hence, the Economist says pandemic diseases and war are so similar to each other. However, in the case of a pandemic, the enemy we are fighting is not a physical person; instead, it is a microscopic virus, making it an invisible battle. The fight against infectious diseases sometimes claims more lives than war and military combat. For example, the Spanish Flu of 1918-1920 killed about 50 million people with a morbidity of $20 \%$ of the world population; as the COVID-19 morbidity and mortality rate increases each day.

Nevertheless, infectious diseases are very deadly and sometimes challenging to conquer. As the impact of a severe pandemic may be comparable to war, violence, economic crisis, hurricane, and earthquake, for instance, the impact of COVI-19. It is causing the death and illness of thousands and millions of people. It compromises people's daily interactions and activities, as their economic and social lives suffer each day. ${ }^{16}$ For instance, there was no vaccine to prevent Ebola during its outbreak, no treatment to cure it, and its morbidity and mortality were on the increase daily. It even appeared to be challenging to hand with sophisticated western medical and scientific technologies. The untamable nature of Ebola caused panic and compromised people's socio-economic activities. However, Ebola can easily and simply be avoided; it is still terrifying and disturbing because of its existence. "Ebola was the red six spades, a painted clown in a darkened cellar: unexpected, unfathomable,

\footnotetext{
${ }^{13}$ The Lancet editorial: COVID-19: learning from experience, MARCH 28, 2020, https://www.thelancet.com/journals/lancet/article/PIIS0140-6736(20)30686-3/fulltext accessed November 15, 2020. ${ }^{14}$ World Health Organization's Regional Office Europe, Protecting nature protects health - lessons for the future from COVID-19, https://www.euro.who.int/en/health-topics/healthemergencies/coronavirus-covid-19/news/news/2020/6/protecting-nature-protects-health-lessons-forthe-future-from-covid-19 accessed November 25, 2020.

${ }^{15}$ Davis Sara. E, Global Politics of health, UK, Polity Press, 2009, 137.

${ }^{16}$ Christian Enemark, Is Pandemic Flu a Security Threat?, Survival, 51:1, 2009, 197.
} 
terrifying."17 Also, there was no vaccine and treatment at the outbreak of COFID-19 in 2020; between March-May, many hospital Intensive Care Units in the United States and most European countries were at optimum capacity. The mobility and mortality rates were high as healthcare workers were overwhelmed with COVID-19 patients. There was a global lockdown of movement, business, religious services, school, and social gathering. Therefore, infectious diseases pose a security threat to countries in three ways; military, socio-economic, and domestic.

First, military, pandemics, and other infectious diseases are a threat to state security. It adversely affects military performance and effectiveness. Because during a military expedition, soldiers often engage in many risky and immoral behaviors that expose them to contagion, such as rape and prostitution, that increase infectious diseases. It may reduce their labor force and may even demoralize them, thereby weaken their efficacy and performance because of infection and illness. There is a concern for the weaponization of disease to be used by military and non-military groups. In the 2001 Anthrax attack against the USA, bioterrorism has been discussed as a major security threat and concern by the Western nations because of the willingness of some groups to use bio-weapon in the past. For example, "Iraq against its Kurdish population in 1998, the attempt by the followers of Rajneesh Bhagwan to spread Salmonella in the US,... the attack on the Tokyo subway using sarin by Aum Shinrikyo in1995 and the 2013 use of a chemical weapon by the Syrian government on its civil population." Moreover, there is an allegation that HIV/AIDS has been used as a psychological or even biological weapon by some African soldiers. ${ }^{18}$ There is also the fear that bio-security and micro-organism may be used as a bio-weapon. ${ }^{19}$ The outbreak and rapid spread of HIV/AIDS in the 1980s and reemergence of more potent microbe-resistant bacteria and viruses that cause malaria, TB, meningitis, and dengue fever have raised the fear and anxiety that bioterrorists might use these deadly bacteria and viruses as weapons to cause more morbidity and mortality. ${ }^{20}$ Hence, infectious diseases should not only be seen as a security threat that weakens the military force and efficacy of a nation. It can also increase the chances of internal violence, ethnoreligious, and political violence, like the \#ENDSARS protest in Nigeria. The \#ENDSARS protest has a connection with lousy governance and COVID -19 outbreak. The protest was a means the Nigerian youths used to express their grievances against the lousy government, especially as the government failed to provide economic and social packages for the people during the COVID-19 lockdown. Also, infectious diseases can be weaponized and used against soldiers and civilians. ${ }^{21}$

Second, another way infectious disease threatens state security is through economic disruption. An outbreak of a pandemic like the COVID-19 lockdown caused much financial burden to the government. Many nations' governments adjusted and readjusted their budget to accommodate the impacts of COVID-19 on their nation's economy and citizen's lives. As mentioned earlier, schools, businesses and airlines, and cruise ship companies suffered heavily. The pandemic reduced productivity and separated workers as some work from

${ }^{17}$ Shah Sonia, Pandemic Tracking Contagions from Cholera to Ebola and Beyond, New York, Picador, 2016, 207-208.

${ }^{18 J e g a t ~ J o s e p h, ~ G l o b a l ~ P a n d e m i c s: ~ A ~ s e c u r i t y ~ t h r e a t, ~ U n i v e r s i t y ~ L e e d s, ~ M a r c h ~ 2015, ~} 3$ available https://www.e-ir.info/2015/11/17/global-pandemics-a-security-threat/ accessed November 27, 2020. ${ }^{19}$ Hank Ten Have, Global Bioethics An Introduction, London, Routledge, 2016, 148

${ }^{20}$ Davis Sara. E, Global Politics of health, UK, Polity Press, 2009, 137.

${ }^{21}$ Jegat Joseph, Global Pandemics: A security threat, University Leeds, March 2015, 3 available https://www.e-ir.info/2015/11/17/global-pandemics-a-security-threat/ accessed November 27, 2020. 
home, and others could not work for many reasons. The economic decline càsed by COVID19 may lead some countries into a great recession. "Although economic decline can in itself be a threat to state security- according to a neo-realist perspective state power is measured in terms of material capability including economic and military strength." Economic recession can translate into internal violent conflict, such as ethnoreligious, socio-political, and domestic violence. ${ }^{22}$ However, a pandemic's economic impact may not be the sole cause of violent conflict. It may catalyst the other preexisting unjust political structure and other social differences to cause violent conflict and crisis in the state. As nations dread war and violent conflict because of their adverse effects on their economic, social, political, health, life, and human developments, so too nations dread an outbreak of infectious disease because it can quickly rack the nation's economy and social structure. ${ }^{23}$

Third, infectious diseases can threaten the socio- domestic life by disrupting the internal societal structure, thereby threatens state security at the most fundamental level. As mention earlier, the panic, anxiety, and separation caused by infectious diseases at the domestic level, home, town, villages, and communities threaten the state's security because of mass exodus and lack of basic means of livelihood. Some people lack confidence in their government because it cannot provide good and affordable healthcare, especially in developing countries. ${ }^{24}$ For instance, the COVID-19 exposed the flawed healthcare system in Nigeria. Some Nigerians were happy with some government officials' deaths because of COVID-19their happiness is because of the officials' inability to travel abroad for medical treatment. Infectious diseases have adverse effects on family life; as experienced during COVID-19, families are separated. Some died in isolation without families and friends. It created depression and increases domestic violence, like incest, rape, and suicide, because of isolation, fear, hopelessness, and relapse. There is a connection between infectious diseases and security because infectious diseases threaten the society at three levels of military force, socioeconomic, and socio-domestic life. As such, it is essential for government, medical and mental institutes to address addiction, suicide, depression, military and economic effects of a pandemic on society as part of their holistic approach in addressing infectious diseases outbreak like COVID-19.

However, as infectious diseases make their way into the USA, United Kingdom, and Australia security agendas, some scholars have warned against such a move's downsides. For instance, Susan Peterson argues that placing infectious diseases on the security agenda may make public health advocates generate undesirable effects by appealing to "high- politics" to health. It essentially implies that human health will be compromised and can only be measured or justified by security impacts and threats. Colin McInnes and Kelley Lee find it sarcastic that some public health officials are using the security implications of infectious diseases as a way of pushing health higher on the policy agenda. It has given rise to increased concern, not for the shifting pattern of health and disease of the global community as a whole, but for selected infectious diseases that possibly threaten the advantaged few. ${ }^{25}$ Colin McInnes and Kelley Lee's view captures the Nigerian experience during the COVID-19 pandemic lockdown. The government enforced a total and compulsory lockdown of all businesses and faced mask-wearing with security agents assigned to arrest and detain

\footnotetext{
${ }^{22}$ Jegat Joseph, Global Pandemics: A security threat, University Leeds, March 2015, 3 available https://www.e-ir.info/2015/11/17/global-pandemics-a-security-threat/ accessed November 27, 2020 ${ }^{23}$ Christian Enemark, Is Pandemic Flu a Security Threat?, Survival, 51:1, 2009, 196. ${ }^{24}$ Jegat Joseph, Global Pandemics: A security threat, University Leeds, March 2015, 2-3 available https://www.e-ir.info/2015/11/17/global-pandemics-a-security-threat/ accessed November 27, 2020 ${ }^{25}$ Christian Enemark, Is Pandemic Flu a Security Threat?, Survival, 51:1, 2009, 199.
} 
defaulter. At the same time, the country has been in an endless war with Boko-Harm and other security challenges for over a decade that have maimed and destroyed the populace's lives and properties without serious and strict security measures to ameliorate the situation. The COVID-19 national lockdown of all business was viewed by some Nigerian as government means of protecting themselves and their family and not for the populace's good.

Furthermore, the difficulty of reconciling health and security with pandemics and infectious diseases, Elbe observed that elevating pandemic influenza to the security agenda may attract priority political attention and a higher resource allocation for public health emergence-response measure. ${ }^{26}$ Again, it may promote abuse and misappropriation of power by the government and security officials, as experienced in Nigeria COVID-19, where security agents used the period to brutalize the people seen or caught moving around during the lockdown of businesses. The government of Nigeria also used COVID-19 as another avenue of embezzlement of public funds and hoarding of food items meant for the populace. Although it is understandable that human rights are not absolute and can be limited for the public good during an emergency; however, the Nigerian COVID-19 was an outrageous situation.

\section{Infectious Disease in African Culture}

In most African societies, health, illness, and diseases are inextricably connected with religious, physical, psychosocial, and biological spheres. It is also not easy to separate religion, culture, and health because most Africans strongly believe in the interconnectedness and the interrelatedness between the spiritual, physical life forces, and human well-being. Hence, diseases, illness, and misfortunes are often given culture-religious interpretations. Often, a time culture-religious approach is used to contain and manage public health disasters and infectious disease ${ }^{27}$ because most illnesses are connected with witchcraft, sorcery, magical power, and gods' anger in rural areas. The implication may that "the sick person or his immediate environment may be regarded as magically contaminated and isolated from others." 28 The cultural-religious approaches include ritual sacrifices, atonement, banishing people from the community, and the oracle's consultation. This supports the idea that cultural and social activities have a strong influence on health and understanding of disease and illness. Although cultural-religious understanding and interpretation of diseases and disasters are not peculiar to African people, many ethnic groups globally approached public health disasters and infectious disease outbreaks from this lens before the development of modern medicine. For instance, in the Dark Ages, "health problems were, for the most part, considered and dealt with in magical and religious terms. Both pagan and Christian sources provided the basis for the supernaturalism of the western Middle Ages... Christianity held that there was a fundamental connection between disease and $\sin ^{.29}$ It demonstrates that globally, humans are concerned about resolving their health, social, natural, and spiritual environment problems with religious, scientific, and cultural means. The application of belief systems and scientific knowledge in resolving human problems sometimes requires moving beyond medical practice to including philosophical questions about the nature of the cosmos,

${ }^{26}$ Christian Enemark, Is Pandemic Flu a Security Threat?, Survival, 51:1, 2009, 200.

${ }^{27}$ Osuji Peter Ikechukwu. African Traditional Medicine: Autonomy and Informed Consent, New York, Springer, 2014, 99-100.

${ }^{28}$ Duru E.J. C and Nwagbos, The Problems and Prospects of Public Health Care Development in Nigeria's Local Government System. Global Journal of Social Sciences Vol. 6, no.1 2007, 52.

${ }^{29}$ Rosen George, A History of Public Health Revised expanded edition. John Hopkins University Press Baltimore, 2015, 19-20. 
moral issues, the concept of person, causation, and nature of knowledge These help to understand who is to blame and what has caused the problem and the solution. Mostly, the answers are sought within the religious circle and cosmology, myth, and philosophy. ${ }^{30}$ The idea of moving beyond medical practice into philosophical questions about diseases and illnesses is Africa's means of diagnosis as they consult the oracle through the native doctor.

However, African, before contact with the Western countries, must have experienced infectious disease outbreaks. The question should be how did they people manage and contain such outbreaks without Western medicine. It is pertinent to understand that isolation, sanitary, and relocation are ancient public health measures employed by most ethnic groups in Africa to contain and manage infectious disease outbreaks. For instance, among the Yoruba, public health beings at the individual level of imototo- transliterated as personal hygiene and good sanitary habit. ${ }^{31}$ Among the Igbo, too, personal hygiene and sanitary are high priced. People are often encouraged to practice cleaning their surroundings and streams. In addition, proper ventilation is not ignored.

The Igbo society often relocates when confronted with any mystery death (epidemic). They often attribute such deaths as the gods' anger or the community's lousy behavior against the gods or goddess. Moreover, containing such an infectious disease outbreak, community effort is required. Each community member cooperates physically and financially to solve the problem and offer their knowledge and talents. The community involvement in health promotion, especially during an outbreak of infectious disease, resonates with the UNESCO declaration principle of solidarity and cooperation. Solidarity and cooperation are rooted in African society because individual life finds meaning in the community. In this case, whatever affects an individual affects the community, and what affects the community affects the individual.

Like many other people worldwide, Africans are much interested in treating and curing illness and relieving the suffering and pains, comforting and encouraging, giving meaning to suffering and life. It is a common practice that people seek and believe that their religion, science, and technology can help solve such a problem. They thereby believe in human creativity and imagination in handling problems. ${ }^{32}$ Hence Everyone contributes to fight and contain an outbreak of infectious diseases. Magical, supernatural, physical, and local herbs are used to treat and contain infectious diseases. For example, during an outbreak of measles or smallpox, the Igbo encourages isolation; both patients and family members are vaccinated with chalk $(n s u)$ and other herbs. Treatment sometimes is given to both the sick and healthy to prevent the spread of the disease. Also, the Amhara ethnic group in Ethiopia classify infection and filth in their etiology of skin diseases. At the same time, the Senufo in Coted'Ivoire, Mali, and Burkina Faso classify natural diseases as those precipitated by some physical feature of the cosmos and differentiate them from diseases from God. Therefore, "what modern medical scientists might understand as contagion in the spread of micro-

\footnotetext{
${ }^{30}$ Rasmussen Susan, Religion and belief system in Falola Toyin and Heaton Matthew. M ed, Health knowledge and Belief system in Africa, North Carolina, Carolina Academic press, 2008, 5 ${ }^{31}$ Afolabi Michael Olusegun, Public Health Disaster: A Global Ethical Framework, Switzerland, Springer, 2018,30

${ }^{32}$ Rasmussen Susan, Religion and belief system in Falola Toyin and Heaton Matthew. M. ed, Health knowledge and Belief system in Africa, North Carolina, Carolina Academic press, 2008, 5
} 
organisms of disease is, in fact, a relatively old idea that originated well before the biomedical theory of microbial vectors of disease."33

\section{COVID-19 Vis-à-Vis Ebola in Africa: Experience and Lesson}

As COVID-19 pandemic cases increase globally, Africa was expected to receive the highest hit because of poverty, corruption, inadequate health care facilities, malnutrition, and lousy government. However, it seems that Africa has defied the COVID-19 expectative scenarios. What might be the reasons for a poor and unequip continent to be doing tremendously well on its management of the COVID-19 pandemic over developed countries? According to the Washington Post: "Ghana is doing much better than America. While so much about the virus and how it operates remains unclear, sub-Saharan Africa so far has dodged a deadly wave of coronavirus cases. Many factors have contributed to this. [Many] West African nations already had a pandemic response infrastructure in place from the Ebola outbreak of late 2013 to 2016." For instance, Liberia lost about 5,000 people to Ebola six years ago; thus, at the beginning of 2020, Liberia quickly started screening for COVID-19 at the airports and quarantining visitors from countries with 200 confirmed cases. ${ }^{34}$ Many African countries strengthened their preparedness against COVID-19 by improving airport surveillance and implementing temperature screening at entry ports. Nigeria and Ethiopia are also interviewing visitors and passengers returning or visiting their countries. They further advised their nationals to avoid traveling to China. They also intensified public health awareness and campaigns within their countries. ${ }^{35}$ After the Ebola pandemic, Senegal sets up an emergency operations center to handle public health crises. This prior arrangement made the COVID-19 testing and its result fast, as some results came out within 24 hours. The country used aggressive contact tracing to get suspected patients. All COVID-19 patients in the country were hospitalized. Senegal, a country of about 16 million, has about 302 deaths from COVID-19. Rwanda, a country with 12 million people, has recorded only 26 deaths from COVID-19 as the USA COVID-19 related death approaches 200,000, as of September 22, 2020. Rwanda has an early and aggressive response to the virus, using equipment and infrastructure keeping in place for HIV/AIDS treatment in managing the pandemic, as both testing and treatment was free. The low COVID-19 death in Africa seems puzzling and mysterious to scientists. It raises a question: "Coronavirus in Africa: Could poverty explain the mystery of low death rate?"36 According to the WHO African Region, as of November 1, 2020, Africa has recorded not more than 1318254 million cases of COVID-19 with 29,901

\footnotetext{
${ }^{33}$ Rasmussen Susan, Religion and belief system in Falola Toyin and Heaton Matthew. M. ed, Health knowledge and Belief system in Africa, North Carolina, Carolina Academic press, 2008, 9

${ }^{34}$ Keren Attiah, Africa has defied the covid-19 nightmare scenarios. We shouldn't be surprise, the Washington Post https://www.washingtonpost.com/people/karen-attiah/ accessed November 22,
} 2020

${ }^{35}$ Gilbert Marius, Preparedness and Vulnerability of Africa countries against importations of COVID19: a modelling study, https://www.thelancet.com/journals/lancet/home accessed November 27, 2020, 875

${ }^{36}$ Keren Attiah, Africa has defied the covid-19 nightmare scenarios. We shouldn't be surprise, the Washington Post https://www.washingtonpost.com/people/karen-attiah/ accessed November 22, 2020 
deaths; however, there is an additional 31621 reported news case and 406 death in the past seven days of this Report. ${ }^{37}$

The COVID-19 pandemic is happening when a global movement challenges anti-Black racism and white supremacy, especially in Western countries. The management of the COVID-19 pandemic in Africa calls on media outlets to change the wrong notion that African countries are incapable of making effective and good governance. This pandemic is also a call on Western countries to learn from Africans' past experiences with previous pandemics and epidemics. "But overall, African countries have made great efforts to contain the [COVID-19,] and the citizens so far have escaped the nightmare predictions. African lives have been saved thanks to the hard work of many dedicated healthcare workers and the collective responsibility of communities." ${ }^{38}$ Some factors may explain African lower cases of COVID-19; these include; different method of recording death, the young demography of Africa, much use of outdoor space for events, and probably the possibilities of higher levels of potentially protective antibodies gained from previous infectious diseases, also to be considered are the weather and the diet, because the African diets consist of herbs and legumes that are rich in fibers and antioxidize. Also, African countries' infectious experiences like SARS, MERS, and Ebola in their institutional memory are an added advantage. As developed countries struggle to combat the virus, the developing countries have shown remarkable success levels because of previous experience, early preparedness, and creativity in handling this pandemic. The way African countries have managed; the COVID-19 has shown that "experience is the best teacher." According to the World Health Organization's weekly bulletin, by the end of September 2020, Sub-Saharan African countries deal with about 116 ongoing infectious disease events, 104 outbreaks, and 12 humanitarian emergencies. The experience and knowledge gained from these infectious diseases made them proactive and willing to use their scarce resources judiciously to prevent and contain any outbreak. "Their mantra might best be summarized as act decisively, act together, and act now. When resources are limited, containment and prevention are the best strategies." 39

Furthermore, African leaders have demonstrated a strong desire to work as a team based on the 2013-2016 West Africa Ebola outbreak. In West Africa, the Ebola outbreak outlines that infectious disease respects no broader. The experience made the African Union set up an African Center for Disease Control and Prevention (CDC.) In April 2020, the Africa CDC went into work, launching its partnership to accelerate COVID-19 testing to increase the region's testing capacity. It trained and deployed healthcare workers across the continent and also sent laboratory equipment and reagents to Nigeria. It also deployed public health workers from the African health Volunteers Corps across the continent to combat the pandemic, using previous knowledge and experience used to fight and combat Ebola. In addition, the African Union established the African Medical supplies Platform (AMSP) for the procurement of laboratory and medical supplies.

${ }^{37}$ WHO African Region, COVID-19 Response in the World Health Organization African Region, February to July, 2020, available at https://www.afro.who.int/publications/covid-19-response-worldhealth-organization-african-region-february-july-2020 accessed November 29, 2020

${ }^{38}$ Keren Attiah, Africa has defied the covid-19 nightmare scenarios. We shouldn't be surprise, the Washington Post https://www.washingtonpost.com/people/karen-attiah/ accessed November 22, 2020

${ }^{39}$ Mormina Maru and Nsofor Ifeanyi.M, What developing countries can teach rich countries about how to respond to pandemic, https://theconversation.com/what-developing-countries-can-teach-richcountries-about-how-to-respond-to-a-pandemic-146784 accessed November 22, 2020 
"The continent behavior as one indivisible unit in fighting the virus, withleaders working together to impose lockdowns, enforce mask requirements and working with continental officials to improve testing and treatment," made it possible for Africa to defy the COVID-19 predictions. According to Dr. John Nkengasong, the director of African Center for Disease Control and Prevention "the key, unifying the leadership of the continent very early in February has been a very critical factor in moderating the spread of the virus on the continent." 40 The solidarity and cooperation among African leaders are Ubuntu's spirit, an indigenous African philosophical concept and practice that provides a normative model that controls and regulates inter-personal human conduct and relationship. That demonstrates that individual existence is meaningful only in a mutual interdependence with the community. It explains African cultural and traditional way of life, practice, and institutional framework. It also embeds the spirit of cooperation and solidarity, as well as the promotion of the common good..$^{41}$ The cooperation and solidarity among African leaders understood from Ubuntu's African philosophy resonated with the Igwebuike or umunnawuike, among the Igbo ethnic group. Igwebuike, which means community, is strength. The Igbo adage a gbako nyuo mmamiri, o gbaa ofufu (when people gather together and urinate, it fumes) captures it well. The coming together in mutual interdependence in the spirit of solidarity and cooperation have saved African countries from the predicted hit of the COVID-19 pandemic. The principle of solidarity and cooperation is the $13^{\text {th }}$ article of the Universal Declaration on Bioethics and human rights. In addition, Ubuntu and Igwebuike's philosophies stress the importance of human interconnectedness and relationships. They also provide a model on which mutual trust, peace, cooperation, and solidarity may flourish among countries and cooperate bodies before, during, and after an outbreak of infectious diseases or pandemic, by promoting compliance to public health directives and measures because "we are all in this together." 42

\section{Conclusion}

Infectious diseases respect no border, and most infectious diseases originate from animals ( wild animals). Humans and animals spread infectious diseases from one place to another because humans move from infected places to noninfectious places. So too, infectious diseases move because human vector diseases flourish on society's border and spread as people seek to avoid material hardship by trading social risk for biomedical ones. Also, infectious diseases are a security threat to state security; they threaten the state security on three levels, military, economic and socio-domestic life. African management of the COVID19 pandemic is based on experience and solidarity because African has previous experiences from past epidemics that have ravaged the continent. The cooperation and solidarity among African leaders were very positive in managing the COVID-19 pandemic in the region. Infectious diseases are connected to the environment in two ways, origin, mobility(movement of people), and socio-economic status.

\section{Bibliography}

40 Premium Times November 17, 2020, Why Africa defied COVID-19 predictions - Disease Control Centre available at https://www.premiumtimesng.com/health/health-news/426630-why-africa-defiedcovid-19-predictions-disease-control-centre.html accessed November 22, 2020.

${ }^{41}$ Afolabi Michael Olusegun, Public Health Disaster: A Global Ethical Framework, Switzerland, Springer, 2018, 45-46.

${ }^{42}$ Afolabi Michael Olusegun, Public Health Disaster: A Global Ethical Framework, Switzerland, Springer, 2018, 47. 


\section{proceedings}

1. Afolabi Michael Olusegun, Public Health Disaster: A Global Ethical Framework, Switzerland, Springer, 2018

2. Christian Enemark, Is Pandemic Flu a Security Threat?, Survival, 51:1, 2009,

3. Davis Sara. E, Global Politics of health, UK, Polity Press, 2009

4. Donaldson Liam and Rutter Paul D, Donaldsons' Essential Public Health $4^{\text {th }}$ Edition, New York, CRC Press, 2018

5. Duru E.J. C and Nwagbos, The Problems and Prospects of Public Health Care Development in Nigeria's Local Government System. Global Journal of Social Sciences Vol. 6, no.1 2007

6. Falola Toyin and Heaton Matthew. M. ed, Health knowledge and Belief system in Africa, North Carolina, Carolina Academic Press, 2008

7. Francis, Encyclical Letter Fratelli Tutti (on Fraternity and Social friendship), Vatican City, Libreria Editrice Vaticana, 2020

8. Francis, Encyclical letter Laudato si'(on care for our common home) Vatican City, Libreria Editrice Vaticana, 2015

9. Gilbert Marius, Preparedness and Vulnerability of Africa countries against importations of COVID-19: a modeling study, https://www.thelancet.com/journals/lancet/home accessed November 27, 2020

10. Hank Ten Have, Global Bioethics An Introduction, London, Routledge, 2016

11. Isiguzo Andrew I et al., The Igbo concept of a Person, Istituto Italiano per l'Africa e l'Oriente, vol. 59, no 2, 2004

12. Jegat Joseph, Global Pandemics: A security threat, University Leeds, March 2015, 3 available https://www.eir.info/2015/11/17/global-pandemics-a-security-threat/ accessed November 27, 2020

13. Keren Attiah, Africa has defied the covid-19 nightmare scenarios. We shouldn't be surprised, the Washington Post https://www.washingtonpost.com/people/karen-attiah/ accessed November 22, 2020

14. Mormina Maru and Nsofor Ifeanyi. M, What developing countries can teach rich countries about how to respond to a pandemic, https://theconversation.com/what-developing-countries-can-teach-rich-countries-about-how-to-respond-to-a-pandemic-146784 accessed November 22, 2020

15. Osuji Peter Ikechukwu. African Traditional Medicine: Autonomy and Informed Consent, New York, Springer, 2014

16. Premium Times November 17, 2020, Why Africa defied COVID-19 predictions - Disease Control Centre available at https://www.premiumtimesng.com/health/health-news/426630-why-africa-defied-covid-19-predictions-disease-controlcentre.html accessed November 22, 2020

17. Rosen George, A History of Public Health Revised expanded edition. John Hopkins University Press Baltimore, 2015

18. Shah Sonia, Pandemic Tracking Contagions from Cholera to Ebola and Beyond, New York, Picador, 2016

19. The Lancet editorial: COVID-19: learning from experience, MARCH 28, 2020

20. WHO African Region, COVID-19 Response in the World Health Organization African Region, February to July 2020, available at https://www.afro.who.int/publications/covid-19-response-world-health-organization-african-region-february-july-2020 accessed November 29, 2020

21. World Health Organization's Regional Office Europe, Protecting nature protects health - lessons for the future from COVID-19, https://www.euro.who.int/en/health-topics/health-emergencies/coronavirus-covid-19/news/news/2020/6/protecting-natureprotects-health-lessons-for-the-future-from-covid-19 accessed November 25, 2020. 